\title{
Antioxidant and antimicrobial potential of selected varieties of Piper betle L. (Betel leaf)
}

\author{
CHAYANIKA SARMA ${ }^{1,2}$, PRASAD RASANE ${ }^{1,3}$, SAWINDER KAUR ${ }^{1,4}$, JYOTI SINGH ${ }^{1}$, JOGINDER \\ SINGH $^{5}$, YOGESH GAT ${ }^{1}$, UMAR GARBA ${ }^{6}$, DAMANPREET KAUR ${ }^{1}$ and KAJAL DHAWAN ${ }^{1}$
${ }^{1}$ Department of Food Technology and Nutrition, Lovely Professional University, GT Road, 144411 Phagwara, Punjab, India ${ }^{2}$ Indian Institute of Food Processing Technology, Pudukkottai Road, 613005 Thanjavur, Tamil Nadu, India ${ }^{3}$ Centre of Food Science and Technology, Banaras Hindu University, Lanka Road, 221005 Varanasi, Uttar Pradesh, India ${ }^{4}$ Sant Longowal Institute of Engineering and Technology, Campus Road, Sangrur, 148106 Longowal, Punjab, India ${ }^{5}$ Department of Microbiology, Lovely Professional University, GT Road, 144411 Phagwara, Punjab, India ${ }^{6}$ Department of Agro-Industry, Naresuan University, Phitsanulok-Nakhonsawan Road, Tapho Sub-District, Muang District, Phitsanulok 65000, Thailand

Manuscript received on March 19, 2018; accepted for publication on July 2, 2018

\begin{abstract}
Piper betle L., is an evergreen perennial creeper belonging to family Piperaceae and is known to possess numerous medicinal properties. Current study focuses on evaluating antioxidant and antimicrobial potential of betel leaf. For the present study, distilled water, hexane, acetone and ethanolic extracts of two varieties of betel leaves: Meetha paan and Banarasi paan were used. Biochemical tests such as proximate analysis (moisture, ash, protein, lipids, minerals viz., sodium and potassium), antioxidant activity tests (DPPH radical scavenging activity, total phenolics, ascorbic acid, reducing power) and antimicrobial test (antibacterial and antifungal susceptibility test) against four pathogens viz., B. subtilis, E. coli, A. niger and $S$. cerevisiae were determined. Ethanolic extract had the highest antioxidant activity ( $89.46 \%$ inhibition), while the aqueous extract exhibited lowest antioxidant activity $(62.03 \%$ inhibition). With increasing concentration $(5,10,25$ and $50 \mu \mathrm{g} / \mathrm{mL})$, the reducing power of leaf extracts also increased. The ascorbic acid was not significant in Banarasi paan $(5.21 \mathrm{mg} / 100 \mathrm{~g})$ and Meetha paan $(5.20 \mathrm{mg} / 100 \mathrm{~g})$. The highest antibacterial activity of ethanolic extract (Banarasi paan) may be attributed to the presence of phytosterols in the leaf varieties. Antioxidant and antimicrobial potential study will help to build a database and promote the utilization of betel leaf as a medicinal herb.
\end{abstract}

Key words: Piper betle, piperaceae, antioxidant, antimicrobial, biochemical.

\section{INTRODUCTION}

Naturally occurring herbs are being used for a long time in food and for medicinal purposes throughout the world. Although, modern approach towards lifestyle has isolated us from the natural

Correspondence to: Prasad Rasane

E-mail: rasaneprasad@gmail.com way of life, mankind so far has been dependent on natural resources for its every need. We have been ignoring the rich natural heritage inherited from our ancestors. This ignorance has aggravated numerous health issues in our day to day lives such as digestive problems, aging problems, etc. However, as the menace of synthetic medicines and food additives in the form of preservatives, coloring agents, 
and antioxidants kept on increasing, mankind is becoming increasingly aware of the natural resources and its benefits. Several researches are now being directed to explore natural herbs for their nutraceutical, antimicrobial and nutritive potential. One such herb of importance is Piper betle L., commonly known as betel leaf.

Betel leaf belongs to the family Piperaceae. It has more than 100 varieties, all over the world of which about 40 of them are found in India. It grows in dry, loam and clay soils that contain high amount of detritus, maintaining a $\mathrm{pH}$ of 7-7.5. These heart shaped leaves are aromatic because of the presence of essential oils and its taste ranges from sweet to pungent (Pradhan et al. 2013). It is locally known as 'paan' in Hindi (India) and is mostly consumed in the form of mouth freshener or appetizer in India.

The betel leaves are nutritive and possess an insecticidal and antitumor activity (Gundala and Aneja 2014), antioxidant activity (Jaiswal et al. 2014), neuroprotective activity (Chan and Wong 2014), antidiabetic and antihelmintic activity (Shah et al.2016), antimicrobial activity (Nouri and Nafchi 2014) and many more. The leaves also contain a variety of biologically active components like hydroxychavicol, chavicol, piperbetol, chavibetol, piperol A, methylpiperbetol, and piperol. The key component of the leaf is a volatile oil known as betle oil (Kumari and Rao 2015, Widawati and Riandi 2015).

The present study was designed to evaluate the nutraceutical properties of two selected, popularly consumed varieties of Piper betle L., namely, Meetha and Banarasi. The antioxidant and antimicrobial potential of these varieties were analyzed. The database is aimed to help promote the utilization of betel leaf in nutraceutical and functional food development.

\section{MATERIALS AND METHODS}

\section{SAMPLE COLLECTION}

Healthy and young betel leaves were procured from the local market of Midnapore, West Bengal and
Varanasi, Uttar Pradesh, India. The local names of different varieties taken for the present study were: Meetha paan (Midnapore, West Bengal, India) and Banarasi paan (Varanasi, Uttar Pradesh, India). The leaf varieties were authenticated in the Department of Botany, Lovely Professional University, Punjab (India).

\section{SAMPLE PREPARATION}

With the help of a chilled mortar and pestle, fresh leaves $(10 \mathrm{~g})$ were ground and dissolved in $100 \mathrm{~mL}$ of respective solvents i.e., distilled water, hexane, acetone, and ethanol (Himedia, India). The extracts were incubated in a shaker incubator (Remi Co., Model CIS 18 Plus, Mumbai, India) overnight at 28 ${ }^{\circ} \mathrm{C}$. Further, the samples were centrifuged at 10,000 rpm for $10 \mathrm{~min}$. All the prepared samples were stored at $-20{ }^{\circ} \mathrm{C}$ until further analysis.

\section{PHYTOCHEMICAL SCREENING}

Different biochemical assays were performed on both varieties of betel leaves extracted with hexane, ethanol, acetone and distilled water for checking the presence of moisture, ash, carbohydrate, protein, lipids, total soluble solid (TSS), vitamin C, total phenolic, sodium and potassium.

\section{PROXIMATE ANALYSIS}

Proximate analysis of samples was carried out according to Association of Offical Analytical Chemists (AOAC) international methods (AOAC 2004). Moisture was determined by drying to a constant weight at $105^{\circ} \mathrm{C}$. Ash content was carried out at $550{ }^{\circ} \mathrm{C}$ (method 923.03). Crude protein (N $\times 6.25$ ) content was determined by the microKjeldahl procedure (method 960.52). Crude lipid content was quantified by extracting the sample with petroleum ether in a Soxhlet apparatus. Total soluble solids (TSS) content for the extract was determined with the help of hand refractrometer of range 0-32 ${ }^{\circ}$ Brix (Model ERMA) as described 
in Ranganna (2007). The potassium and sodium content of leaves was determined by the method described in Ranganna (2007).

\section{DETERMINATION OF ANTIOXIDANT ACTIVITY}

Free radical scavenging activity was determined using DPPH radical on the basis of scavenging ability of the extracts of betel on 2,2-diphenyl1-picrylhydrazyl (DPPH) free radicals (Jenitha and Anusuya 2016). The reducing power was determined by ferricyanide-ferric chloride method as described by Shiban et al. (2012). Total phenolic content of the sample was determined spectrophotometrically at $765 \mathrm{~nm}$ by using folin-ciocalteu's reagent (Rasane et al. 2015). Ascorbic acid content was determined using 2,6-dichlorophenol indophenol dye (AOAC 2004).

\section{DETERMINATION OF ANTIMICROBIAL ACTIVITY}

\section{Antifungal and antibacterial susceptibility test}

Two different betel leaf extracts were tested against four microorganisms viz; Escherichia Coli (gram negative), Aspergillus niger (fungi), Bacillus subtilis (gram positive), and Saccharomyces cerevisiae (yeast). Agar well diffusion method was used for testing anti-microbial activity of four sample extract. Antibacterial activity was determined by measuring the zone of inhibition $(\mathrm{mm})$ around the well (Chakraborty and Shah 2011).

\section{STATISTICAL ANALYSIS}

Means and standard deviations of three replicates were determined for all the analysis in the present study. Significant difference of mean values was assessed by one-way analysis of variance (ANOVA) followed by Duncan's LSD test using the commercial statistical package SPSS ver.11.5 (SPSS Inc., Chicago, IL, USA) at a significance level of $(\mathrm{p} \leq 0.05)$.

\section{RESULTS AND DISCUSSION}

\section{NUTRITION AND PHYTOCHEMICAL PROFILE OF BETEL LEAF}

The nutritional and phytochemical profile of the betel leaf was analyzed and the result is shown in the Table I. The composition of lipids, vitamin $\mathrm{C}$ and total ash, including sodium and potassium content showed no significant ( $\mathrm{p}>0.05$ ) difference in both the varieties (Meetha and Banarasi) of leaves. There was slightly significant difference in the carbohydrates and protein amongst the two varieties of the leaves. The results were in accordance with the findings of Shah et al. (2016). The presence of the five industry' standard proximate composition reveals the nutritive value of the leaves (Table I). The essential oil contained in the leaves is known to possess antifungal, antibacterial and antiprotozoan properties with the potential to kill or inhibit the growth of disease causing bacteria. The significant vitamin and mineral content of leaves also adds to its nutritive value (Guha 2006). Betel leaf oil contains a phenol called chavinol, which has antiseptic properties. It was also reported by Dwivedi and Tripathi (2014) that, the chavinol in betel leaf is an aromatic compound responsible for the spicy odor of the leaves. Total soluble solids

TABLE I

Phytochemical screening of betel leaf.

\begin{tabular}{lcc}
\hline Phytochemicals & Banarasi & Meetha \\
\hline Moisture (\%) & $84.83 \pm 0.38^{\mathrm{b}}$ & $86.48 \pm 0.27^{\mathrm{a}}$ \\
Ash (\%) & $4.30 \pm 0.07^{\mathrm{a}}$ & $4.20 \pm 0.03^{\mathrm{a}}$ \\
Carbohydrate (\%) & $5.03 \pm 0.03^{\mathrm{a}}$ & $5.20 \pm 0.05^{\mathrm{b}}$ \\
Protein (\%) & $3.20 \pm 0.03^{\mathrm{b}}$ & $3.34 \pm 0.05^{\mathrm{b}}$ \\
Lipids (\%) & $0.80 \pm 0.04^{\mathrm{a}}$ & $0.78 \pm 0.02^{\mathrm{a}}$ \\
TSS ( ${ }^{\circ}$ Brix) & $23.00 \pm 0.08^{\mathrm{a}}$ & $23.03 \pm 0.06^{\mathrm{a}}$ \\
Total phenolics (mg/100 gm) & $13.08 \pm 2.03^{\mathrm{b}}$ & $15.03 \pm 0.04^{\mathrm{a}}$ \\
Vitamin C (mg/100 gm) & $5.21 \pm 0.01^{\mathrm{a}}$ & $5.20 \pm 0.06^{\mathrm{a}}$ \\
Sodium (mg/100 gm) & $11.37 \pm 0.44^{\mathrm{a}}$ & $11.35 \pm 0.03^{\mathrm{a}}$ \\
Phosphorus (mg/100 gm) & $41.54 \pm 0.07^{\mathrm{a}}$ & $40.33 \pm 0.02^{\mathrm{b}}$ \\
\hline
\end{tabular}

Mean values with different superscripts on the same row differ significantly (Duncan's LSD test, $\mathrm{p}<0.05$ ). 
(TSS) of the betel leaves was found to be 24.0 ${ }^{\circ}$ Brix in the Banarasi variety and $23.0^{\circ}$ Brix in the Meetha variety. Similar results for the TSS on Piper betle L., were obtained in the study carried out by Guha (2006) and Pradhan et al. (2013).

\section{ANTIOXIDANT ACTIVITY AND ASCORBIC ACID CONTENT}

Free radical reactions occurring in the body are associated with numerous diseases and health problems such as cardiovascular diseases, neurological diseases, cancer and pulmonary diseases. These free radicals play a major role in the aging process. Antioxidants are the potential solution to encounter such anomalies. Naturally occurring antioxidants such as total polyphenols, vitamins, etc., present in herbs are involved in scavenging these free radicals. For the present study antioxidant activity of different betel leaf extracts were screened by free radical scavenging activity, measurement of reducing power, total polyphenol content and ascorbic acid content. The antioxidant activity is attributed to the phenol and flavonoid content of the leaves. Higher the content, the more is the antioxidant and radical scavenging activity. Studies by Rintu et al. (2015) revealed that variety with maximum total phenolic content exhibited maximum antioxidant and free radical scavenging activities. The present study was also in accordance with the above results.

\section{FREE RADICAL SCAVENGING ACTIVITY}

Free radicals are reactive oxygen species generated by cellular oxidative pathway. An imbalance in the generation and removal of these reactive species damages the biomolecules of cells, resulting in chronic diseases (Lee et al. 2009). Shah et al. (2016) also reported that betel leaf extracts exhibited free radical scavenging activity. The free radical scavenging activity was found to be maximum in the ethanolic extract (89.46\% inhibition) and lowest (62.03\% inhibition) in the distilled water extract.
Similar observations were reported by Shah et al. (2016) and thus the ethanolic extract can be used in extending the shelf life of various products. Table II summarizes the DPPH scavenging activity and the descending order of the extracts can be arranged as follows Ethanolic Meetha (EM) > Ethanolic Banarasi (EB) > Acetonic Banarasi (AB) > Acetonic Meetha (AM) > Hexane Banarasi (HB) $>$ Hexane Meetha $(\mathrm{HM})>$ Distilled Water Banarasi (DWB) $>$ Distilled Water Meetha (DWM). The results are comparable with that reported by Dasgupta and De (2004) for Piper betle L. Jaiswal et al. (2014) reported high antioxidant activity in the leaves because of the presence of phenolic compound hydroxyl chavicol (4-allyl pyrocatechol) and is proving to be a better preservative. Shah et al. (2016) reported that hydroxyl chavicol is effective against several strains of fungi and thus acts as a preservative.

\section{TOTAL POLYPHENOLIC CONTENT}

Polyphenols have assembled huge popularity due to their antioxidant properties and defending

TABLE II

Antioxidant activity of betel leaf extracts.

\begin{tabular}{cc} 
Samples & $\begin{array}{c}\text { Free radical scavenging activity } \\
\text { (\% inhibition) }\end{array}$ \\
\hline AM & $82.28 \pm 0.43^{\mathrm{d}}$ \\
AB & $85.34 \pm 0.32^{\mathrm{c}}$ \\
HM & $76.40 \pm 0.55^{\mathrm{f}}$ \\
HB & $78.73 \pm 0.70^{\mathrm{e}}$ \\
EM & $87.34 \pm 0.32^{\mathrm{b}}$ \\
EB & $89.46 \pm 0.54^{\mathrm{a}}$ \\
DWM & $62.03 \pm 0.05^{\mathrm{h}}$ \\
DWB & $74.68 \pm 0.56^{\mathrm{g}}$
\end{tabular}

AM: acetone meetha, $\mathrm{AB}$ : acetone banarasi, HM: hexane meetha, HB: hexane banarasi, EM: ethanol meetha, EB: ethanol banarasi, DWM: distilled water meetha, DWB: distilled water banarasi.

Mean values with different superscripts on the same column differ significantly (Duncan's LSD test, $\mathrm{p}<0.05$ ). 
actions against ultraviolet radiation or aggression by pathogens, parasites and predators. It has one or more aromatic rings with one or more aromatic group (Dai and Mumper 2010). The polyphenolic content of the betel leaf was 15.03 and 13.08 TAEmg/100 g, in Meetha and Banarasi varieties respectively, and varied significantly $(p<0.05)$ amongst the varieties. For the antioxidant activity, the major components of Piper betle L. are chavinol, chavibetol, allylprotocatechol and eugenol (Jaiswal et al. 2014, Dwivedi and Tripathi 2014). The presence of phenolic compound contributes to the antioxidant activity of the leaves and allows them to act as reducing agents, hydrogen donors, singlet oxygen quenchers, heavy metal chelators and hydroxyl radical quenchers (Jha et al. 2011).

\section{MEASUREMENT OF FERRIC REDUCING ANTIOXIDANT POWER}

Table III depicts the measurement of the reductive ability of leaf extracts. Reducing power of the extract is mainly due to the phenolic compounds and flavonoids present in raw formulations. Phenolic compounds and flavonoids have the ability to donate electrons and act as reductones and play a major role in the reducing power of the extracts (Gat and Ananthanarayan 2015). Shah et al. (2016) has shown that an ethyl acetate extract of betel leaf showed maximum $\mathrm{Fe}^{2+}$ ion reducing ability owing to its high phenolic content. Maximum activity was observed in the AM variety
$(25 \mu \mathrm{g} / \mathrm{mL})$ and the lowest was observed in the EB variety $(5 \mu \mathrm{g} / \mathrm{mL})$. It was observed that along with the increase in concentration, there was an increase in absorbance. Higher absorbance indicates that the leaves possess strong reducing power. Study by Chakraborty and Shah (2011) using four extracts (methanol, aqueous, petroleum ether and ethyl acetate) have revealed similar results.

\section{ASCORBIC ACID CONTENT}

Various physiological functions including the synthesis of collagen, neurotransmitters and carnitine are carried out by vitamin $\mathrm{C}$ and it is regarded as the most important antioxidant. It is a strong reducing agent, and it is absence may lead to delay in wound healing and failure in repairing fractures (Molnar et al. 2014). The healing action is attributed to free radical scavenging activity (Shah et al. 2016). In the Banarasi and Meetha variety of leaf, vitamin $\mathrm{C}$ content was found to be 5.21 and $5.20 \mathrm{mg} / 100 \mathrm{~g}$, respectively as illustrated in Table I. Similar data were recorded in a study carried out by Guha (2006) for Piper betle L. leaves. The presence of vitamin $\mathrm{C}$ indicates that, the leaves will act as superoxide neutralizer, oxygen quencher, a hydroxyl radical scavenger and promote antioxidant activity (Aguirre and May 2008). Saravanan et al. (2003) investigated and reported that, consumption of betel leaf increased the serum antioxidants like vitamin $\mathrm{C}$ and vitamin $\mathrm{E}$. The leaves should

TABLE III

Reduction power of betel leaf extracts.

\begin{tabular}{ccccccccc}
\hline $\begin{array}{c}\text { Samples conc. } \\
(\boldsymbol{\mu g} / \mathbf{m L})\end{array}$ & $\mathbf{A M}$ & $\mathbf{H M}$ & $\mathbf{E M}$ & $\mathbf{D W M}$ & $\mathbf{A B}$ & $\mathbf{H B}$ & $\mathbf{E B}$ & $\mathbf{D W B}$ \\
\hline 5 & $0.70 \pm 0.004^{\mathrm{d}}$ & $0.25 \pm 0.03^{\mathrm{d}}$ & $0.13 \pm 0.34^{\mathrm{c}}$ & $0.36 \pm 0.43^{\mathrm{a}}$ & $0.65 \pm 0.03^{\mathrm{c}}$ & $0.22 \pm 0.23^{\mathrm{d}}$ & $0.12 \pm 0.23^{\mathrm{c}}$ & $0.33 \pm 0.44^{\mathrm{b}}$ \\
10 & $0.89 \pm 0.12^{\mathrm{c}}$ & $0.27 \pm 0.04^{\mathrm{c}}$ & $0.13 \pm 0.20^{\mathrm{c}}$ & $0.37 \pm 0.10^{\mathrm{a}}$ & $0.68 \pm 0.43^{\mathrm{c}}$ & $0.26 \pm 0.14^{\mathrm{c}}$ & $0.15 \pm 0.33^{\mathrm{b}}$ & $0.34 \pm 0.10^{\mathrm{b}}$ \\
25 & $0.97 \pm 0.22^{\mathrm{a}}$ & $0.29 \pm 0.23^{\mathrm{b}}$ & $0.15 \pm 0.02^{\mathrm{b}}$ & $0.39 \pm 0.32^{\mathrm{a}}$ & $0.77 \pm 0.12^{\mathrm{a}}$ & $0.29 \pm 0.44^{\mathrm{a}}$ & $0.17 \pm 0.43^{\mathrm{ab}}$ & $0.36 \pm 0.04^{\mathrm{ab}}$ \\
50 & $0.95 \pm 0.03^{\mathrm{b}}$ & $0.34 \pm 0.20^{\mathrm{a}}$ & $0.16 \pm 0.35^{\mathrm{a}}$ & $0.38 \pm 0.08^{\mathrm{a}}$ & $0.72 \pm 0.06^{\mathrm{b}}$ & $0.33 \pm 0.52^{\mathrm{b}}$ & $0.19 \pm 0.12^{\mathrm{a}}$ & $0.39 \pm 0.22^{\mathrm{a}}$ \\
\hline
\end{tabular}

AM: acetone meetha, AB: acetone banarasi, HM: hexane meetha, HB: hexane banarasi, EM: ethanol meetha, EB: ethanol banarasi, DWM: distilled water meetha, DWB: distilled water banarasi.

Mean values with different superscripts on the same column differ significantly (Duncan's LSD test, $\mathrm{p}<0.05$ ). 
be stored in a favorable condition to ensure the quantity retention in order to treat various diseases.

\section{ANTIMICROBIAL ACTIVITY}

\section{Antibacterial susceptibility test}

Antimicrobial activity was seen with respect to all the leaf extracts viz; aqueous, hexane, acetone and ethanol. The notable antibacterial effect was observed in relation to aqueous, hexane, acetone and ethanolic extracts. All extracts were effective against the test microorganisms.

Ethanolic extract of Banarasi variety reported highest antibacterial activity against Bacillus subtilis. Datta et al. (2011) reported that ethanolic and methanolic extracts of Piper betle L., possesses antimicrobial activity against pathogens (gram positive and negative). It was also shown by Agarwal et al. (2012) that aqueous, acetonic, methanolic and ethanolic extracts of Piper betle L., possess antimicrobial activity against both gram positive and gram negative pathogens with ethanolic extract having maximum activity. A zone of inhibition ( $\mathrm{mm}$ ) of Ethanolic extract of Banarasi and Meetha variety of leaves against various pathogens (B.subtilis, E. coli, and S. cerevisiae) is shown in Figure 1a, b, and c. Methanolic and ethanolic extract exhibited potent antibacterial activity against various pathogens. However, Kaur and Mondal (2014) showed that Piper betle L., extract are inactive against $E$. coli and $S$. aureus. The susceptibility of gram positive bacterial strains was found to be more because of simple cell wall along with small pores in the outer layer of the cell which possess a natural sieve effect against large molecules (Sugumaran et al. 2011). The antibacterial activity may be due to sterol, which is found in abundance in the betel leaf extracts and due to the surface interaction of the leaf extracts with the cell wall of bacteria thereby, destroying the bacterial components. The antibacterial activity is attributed to polyphenols (Tan and Chan 2014).

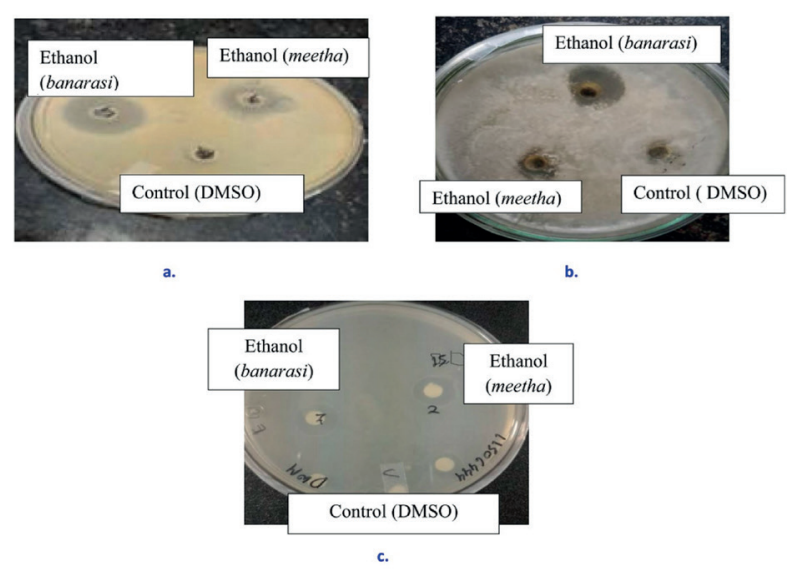

Figure 1 - Zone of inhibition ( $\mathrm{mm}$ ) of ethanolic extracts on a. Bacillus subtilis, b. E. coli, c. Saccharomyces cerevisiae.

Hoque et al. (2012) observed antibacterial activity against some spoilage microorganisms and food borne pathogens using ethanolic extract. The zone of inhibition is maximum for ethanolic extracts which is in accordance with the results of Agarwal et al. (2012). The results also suggested that compounds present in the betel leaf extract possess antibacterial properties against various pathogens. Antibacterial properties possessed by an ethanolic extract would be fruitfully utilized to extend the shelf-life of food or food products.

\section{INHIBITION ZONE}

Inhibition zone was found to be the highest for the DWM. Similar results were found in the study carried out by Chakraborty and Shah (2011). Various studies narrated that the betel leaf extract contains betel oil that possess antioxidant and antimicrobial properties (Jaiswal et al. 2014, Nouri and Nafchi 2014). Figure 2 depict the inhibition zone produced by different leaf extracts against $B$. subtilis, E. coli, A. niger and S. cerevisiae.

Previous studies on Piper betle L., extracts having high concentration of fatty acids like stearic acid, palmitic acid and hydroxy fatty acid esters showed positive antimicrobial activity against a wide range of pathogens (Khan and Kumar 2011). 


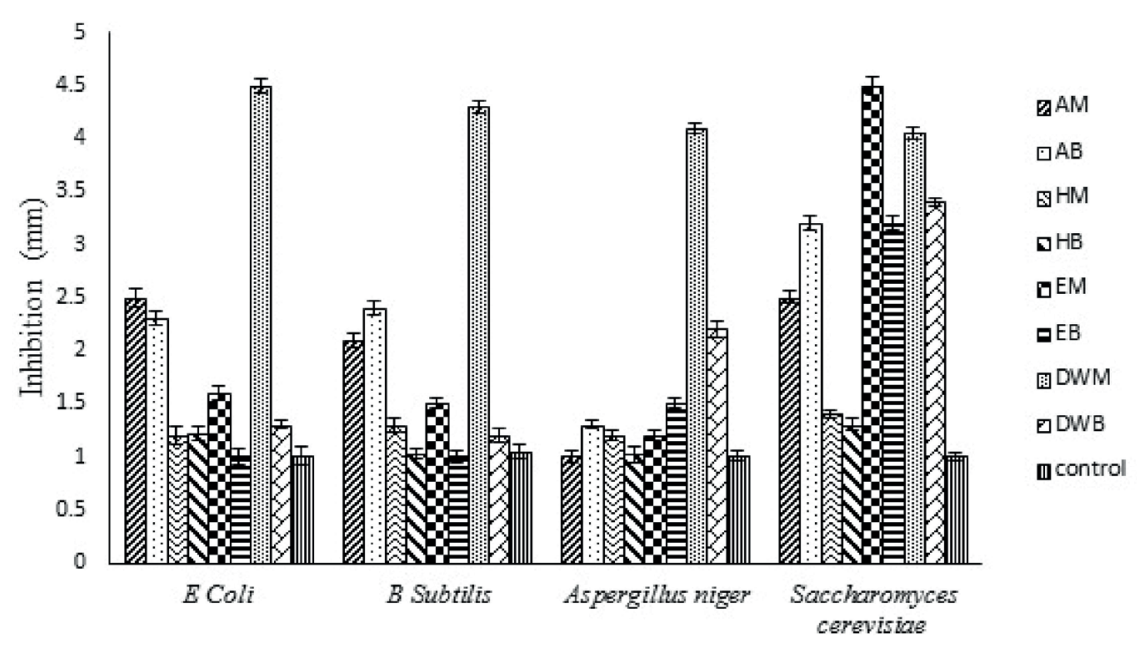

Figure 2 - Inhibition zone ( $\mathrm{mm}$ ) produced by different betel leaf extracts against various pathogens. Where, AM- Acetone Meetha, AB- Acetone Banarasi, HM- Hexane Meetha, HB- Hexane Banarasi, EM- Ethanol Meetha, EB- Ethanol Banarasi, DWM- Distilled Water Meetha, DWB- Distilled Water Banarasi

Ethanolic extract showed maximum inhibition zone against E. coli followed by $S$. aureus. All extracts (ethanol, distilled water, hexane and acetone) showed inhibition zone $(\mathrm{mm})$ against all fungi, bacteria and yeast in the present study. Hexane, acetone and aqueous extracts showed higher inhibition than the ethanolic extracts. Lowest inhibition was observed in the EB and EM against $B$. subtilis and E. coli which indicates higher effectiveness. Deshpande and Kadam (2013) reported that the minimum inhibitory concentration (MIC) of ethyl acetate, methanol, petroleum ether extracts was low as compared to chloroform extract, and further stated that, the lower the minimum inhibitory concentration (MIC), the more effective is the betel leaf extract.

\section{CONCLUSIONS}

The present study unveiled the antimicrobial potential of Piper betle L. extracts. Ethanolic extracts showed the most effective result. The leaves are a good source of natural antioxidant for the pharmaceutical industry, that will accomplish desirable therapeutic outcomes and can be of great potential as a health care resource for fighting against various pathogens.

\section{ACKNOWLEDGMENTS}

The authors are thankful to the Department of Biotechnology and the Department of Food Technology and Nutrition, Lovely Professional University, Jalandhar, Punjab, India, for providing the infrastructure to perform the experiment.

\section{REFERENCES}

AGARWAL T, SINGH R, SHUKLA AD, WARIS I AND GUJRATI A. 2012. Comparative analysis of antibacterial activity of four Piper betle varieties. Adv Appl Sc Res 3: 698-705.

AGUIRRE R AND MAY JM. 2008. Inflammation in the vascular bed: importance of vitamin C. Pharmacol Ther 119(1): 96-103.

AOAC - ASSOCIATION OF OFFICIAL ANALYTICAL CHEMISTS. 2004. Official methods of analysis. The association of official analytical chemists, Washington, DC, p. 125-139.

CHAKRABORTY D AND SHAH B. 2011. Antimicrobial, antioxidative and antihemolytic activity of Piper betel leaf extracts. Int J Pharm Pharm Sci 3(3): 192-199. 
CHAN EWC AND WONG SK. 2014. Phytochemistry and pharmacology of three Piper species: An update. J Phcog 1(9): 534-544.

DAI J AND MUMPER RJ. 2010. Plant phenolics: extraction, analysis and their antioxidant and anticancer properties. Molecules 15(10): 7313-7352.

DASGUPTA N AND DE B. 2004. Antioxidant activity of Piper betle L. leaf extract in vitro. Food Chem 88(2): 219224.

DATTA A, GHOSHDASTIDAR S AND SINGH M. 2011. Antimicrobial property of Piper betel leaf against clinical isolates of bacteria. Int J Pharma Sci Res 2(3): 104-109.

DESHPANDE S AND KADAM D. 2013. Phytochemical analysis and antibacterial activity of Acacia nilotica against Streptococcus mutans. Phytochem Anal 5(1): 236238.

DWIVEDI V AND TRIPATHI S. 2014. Review study on potential activity of Piper betle. J Pharmacogn Phytochem 3(4): 93-98.

GAT Y AND ANANTHANARAYAN L. 2015. Physicochemical, phytochemical and nutritional impact of fortified cereal-based extrudate snacks. Nutrafoods 14(3): 141-149.

GUHA P. 2006. Betel leaf: the neglected green gold of India. Hum Ecol 19(2): 87-93.

GUNDALA SR AND ANEJA R. 2014. Piper betel leaf: a reservoir of potential xenohormetic nutraceuticals with cancer-fighting properties. Cancer Prev Res 7(5): 477-486.

HOQUE MM, RATTILA S, SHISHIR MA, BARI ML, INATSU Y AND KAWAMOTO S. 2012. Antibacterial activity of ethanol extract of betel leaf (Piper betle L.) against some food borne pathogens. Bangladesh $\mathrm{J}$ Microbiol 28(2): 58-63.

JAISWAL SG, PATEL M, SAXENA DK AND NAIK SN. 2014. Antioxidant properties of Piper betle (L.) leaf extracts from six different geographical domain of India. Journal of Biores Engg Technol 2(2): 12-20.

JENITHA AX AND ANUSUYA A. 2016. Phytochemical screening and in vitro antioxidant activity of ananas comosus. J Research Pharma Pharmacotherap 5(2): 162-169.

JHA A, UPADHYAY A, RASANE P AND SINGH HB. 2011. Quantitative studies of phytochemicals of selected green leafy vegetables and their antioxidant potential. Med Plant-Int J Phytomed Rel Ind 3(2): 113-117.

KAUR S AND MONDAL P. 2014. Study of total phenolic and flavonoid content, antioxidant activity and antimicrobial properties of medicinal plants. J Microbiol Exp, $6 \mathrm{p}$.

KHAN JA AND KUMAR N. 2011. Evaluation of antibacterial properties of extracts of Piper betel leaf. J Pharm Biomed Sci 11(11): 1-3.

KUMARI OS AND RAO NB. 2015. Phyto Chemical Analysis of Piper betle Leaf Extract. World J Pharm Pharm Sci 4: 699-703.
LEE OH, LEE BY, LEE J, LEE HB, SON JY, PARK CS, SHETTY K AND KIM YC. 2009. Assessment of phenolics-enriched extract and fractions of olive leaves and their antioxidant activities. Bioresour Technol 100(23): 6107-6113.

MOLNAR JA, UNDERDOWN MJ AND CLARK WA. 2014. Nutrition and chronic wounds. Adv Wound Care 3(11): 663-681.

NOURI LAND NAFCHI AM. 2014. Antibacterial, mechanical, and barrier properties of sago starch film incorporated with betel leaves extract. Int J Biol Macromol 66: 254-259.

PRADHAN D, SURI KA, PRADHAN DK AND BISWASROY P. 2013. Golden heart of the nature: Piper betle L. J Pharmacogn Phytochem 1(6): 147-167.

RANGANNA S. 2007. Handbook of analysis and quality control for fruit and vegetable products. New Delhi: Tata McGraw-Hill Publishing Co., Limited, p. 105-106.

RASANE P, JHA A, KUMAR A AND SHARMA N. 2015. Reduction in phytic acid content and enhancement of antioxidant properties of nutricereals by processing for developing a fermented baby food. J Food Sci Technol 52(6): 3219-3234.

RINTU D, SHINJINI M, KAUSTAB M, PRAMATHADHIP P, UMESH PS AND BANERJEE ER. 2015. Anti-oxidant and anti-inflammatory activities of different varieties of Piper leaf extracts (Piper betle L.). Nutr Food Sci 5(5): $1-15$.

SARAVANAN R, RAJENDRA PRASAD N AND PUGALENDI KV. 2003. Effect of Piper betle leaf extract on alcoholic toxicity in the rat brain. J Med Food 6(3): 261-265.

SHAH SK, GARG G, JHADE D AND PATEL N. 2016. Piper betle: phytochemical, pharmacological and nutritional value in health management. Int J Pharm Sci Rev Res 38: 181-189.

SHIBAN MS, AL-OTAIBI MM AND AL-ZOREKY NS. 2012. Antioxidant activity of pomegranate (Punica granatum L.) fruit peels. Food Nutr Sci 3(7): 991.

SUGUMARAN M, GANDHI S, SANKARNATAYANEN M, YOKESH M, POORNIME M AND RAJASEKHAR SM. 2011. Chemical composition and antimicrobial activity of vellaikodi variety of Piper betle L. leaf oil against dental pathogens. Int J Pharm Techn Res 3: 2135-2139.

TAN YP AND CHAN EWC. 2014. Antioxidant, antityrosinase and antibacterial properties of fresh and processed leaves of Anacardium occidentale and Piper betle. Food Biosci 6: 17-23.

WIDAWATI M AND RIANDI MU. 2015. Study of Herbal Topical Repellent Made of Betel Leaves (Piper betle) and Patchouli Oil (Pogostemon cablin) Mixture Against Yellow Fever Mosquito (Aedes aegypti). BIOTROP 22(1): 45-51. 